University of Nebraska - Lincoln

DigitalCommons@University of Nebraska - Lincoln

\title{
Use of OSL dating to establish the stratigraphic framework of Quaternary eolian sediments, Anton scarp upper trench, Northeastern Colorado High Plains, USA
}

\author{
Shannon A. Mahan \\ U.S. Geological Survey, smahan@usgs.gov \\ David C. Noe \\ Colorado Geological Survey, dave.noe@state.co.us \\ James P. McCalpin \\ Geo-Haz Consulting, Inc., mccalpin@geohaz.com
}

Follow this and additional works at: https://digitalcommons.unl.edu/usgsstaffpub

Part of the Earth Sciences Commons

\begin{abstract}
Mahan, Shannon A.; Noe, David C.; and McCalpin, James P., "Use of OSL dating to establish the stratigraphic framework of Quaternary eolian sediments, Anton scarp upper trench, Northeastern Colorado High Plains, USA" (2009). USGS Staff -- Published Research. 430.

https://digitalcommons.unl.edu/usgsstaffpub/430
\end{abstract}

This Article is brought to you for free and open access by the US Geological Survey at DigitalCommons@University of Nebraska - Lincoln. It has been accepted for inclusion in USGS Staff -- Published Research by an authorized administrator of DigitalCommons@University of Nebraska - Lincoln. 


\title{
Use of OSL dating to establish the stratigraphic framework of Quaternary eolian sediments, Anton scarp upper trench, Northeastern Colorado High Plains, USA
}

\author{
Shannon A. Mahan ${ }^{\mathrm{a}, *}$, David C. Noe ${ }^{\mathrm{b}}$, James P. McCalpin ${ }^{\mathrm{c}}$ \\ ${ }^{a}$ US Geological Survey, Denver Federal Center, MS 974, Box 25046, Denver, CO 80225, USA \\ ${ }^{\mathrm{b}}$ Colorado Geological Survey, 1313 Sherman Street, Rm. 715, Denver, CO 80203, USA \\ ${ }^{\mathrm{c}}$ GEO-HAZ Consulting, Inc., Box 837, Crestone, CO 81131, USA
}

Available online 21 October 2008

\begin{abstract}
This paper contains the results of the optically stimulated luminescence (OSL) dating used to establish stratigraphic ages and relationships of eolian sediments in a trench in northeastern Colorado, USA. This trench was located in the upper face of the Anton scarp, a major topographic lineament trending NW-SE for a distance of $135 \mathrm{~km}$, in anticipation of intersecting near-surface faulting. The trench was $180 \mathrm{~m}$ long, 4.5-6.0 $\mathrm{m}$ deep, and exposed $22 \mathrm{~m}$ of stratigraphic section, most of which dipped gently west and was truncated by gulley channeling at the face of the scarp. No direct evidence of faulting was found in the upper trench. The stratigraphy from the trench was described, mapped and dated using OSL on quartz and potassium feldspar, and ${ }^{14} \mathrm{C}$ obtained from woody material. OSL dating identified two upper loess units as Peoria Loess and Gilman Canyon Loess, deposited between 16 and 30 ka ago. The bottom layers of the trench were substantially older, giving OSL ages in excess of $100 \mathrm{ka}$. These older ages are interpreted as underestimates, owing to saturation of the fast component of OSL.

Using OSL and ${ }^{14} \mathrm{C}$ dating, we can constrain the erosion and down cutting of the scarp face as occurring between 16 and $5.7 \mathrm{ka}$. As the trenching investigation continues in other parts of the scarp face, the results of this preliminary study will be of importance in relating the ages of the strata that underlie different parts of the scarp, and in determining whether Quaternary faulting was a mechanism that contributed to the formation of this regional geomorphic feature.

Published by Elsevier Ltd.
\end{abstract}

\section{Introduction}

The mid-continent region of the United States has been well studied for its loess deposits (Roberts et al., 2007), but geochronologic studies of these deposits along their far western periphery (where they thin dramatically and become irregular in coverage), have been rare. Such studies are particularly important for applications in paleoseismology, where the timing and offset of young deposits are key questions of concern (McCalpin, 1996; Crone et al., 1997).

The Great Plains is a dominant physiographic province of the United States and encompasses the eastern $40 \%$ of

\footnotetext{
*Corresponding author. Tel.: +13032367928.

E-mail addresses: smahan@usgs.gov (S.A. Mahan), dave.noe@state.co.us (D.C. Noe), mccalpin@geohaz.com (J.P. McCalpin).
}

the state of Colorado. Colorado's eastern portion is further subdivided into the Colorado Piedmont (closest to the Front Range Mountains) and the High Plains. The salient features of the High Plains are large flat divides of rolling grassland that lie between and adjacent to the valleys of the South Platte and the Arkansas Rivers (Topper et al., 2003). The High Plains receive a long-term annual average precipitation of $30-40 \mathrm{~cm}$ year $^{-1}$, with much of this precipitation occurring between March and June (Colorado State University, 2007). The climate is semi-arid with hot summers and cold winters, high to moderate winds, large daily temperature fluctuations and little precipitation.

Colorado's High Plains consist of a broad expanse of Miocene and younger sediments that dip gently eastward into Kansas and Nebraska. This region is crossed by numerous lineaments and escarpments, many of which have a NW-SE orientation. Recent digital elevation 
models depicting the eastern portion of Colorado reveal the largest of these topographic lineaments (informally named the Anton Scarp) trends NW-SE and extends unbroken for a distance of at least $135 \mathrm{~km}$ (Matthews, 2004) (Fig. 1a).

The northeast-facing lineament is $20-30 \mathrm{~m}$ in height. McGovern (1964) mapped the lineament as the contact between a broad plateau containing Pleistocene Peoria Loess to the southwest and a topographically lower area floored by the late Tertiary (Miocene/Pliocene) Ogallala Formation to the northeast. He considered the lineament to be the edge of one of several ridges of loess that were deposited parallel to the direction of then-prevailing winds.

Matthews (2004) suggested that the lineament might be the product of strike-slip faulting because it is such a strikingly linear feature and contains left-stepping enechelon sections, three ephemeral streams that have distinct left-lateral bends of about $1.6 \mathrm{~km}$ each, and what appears to be two synthetic shears splaying off the main lineament.

In 2004, the Colorado Geological Survey and its research partners trenched the upper face of the lineament $11 \mathrm{~km}$ northeast of Anton, $\mathrm{CO}$, USA, at $39.8230^{\circ} \mathrm{N}, 103.1438^{\circ} \mathrm{W}$
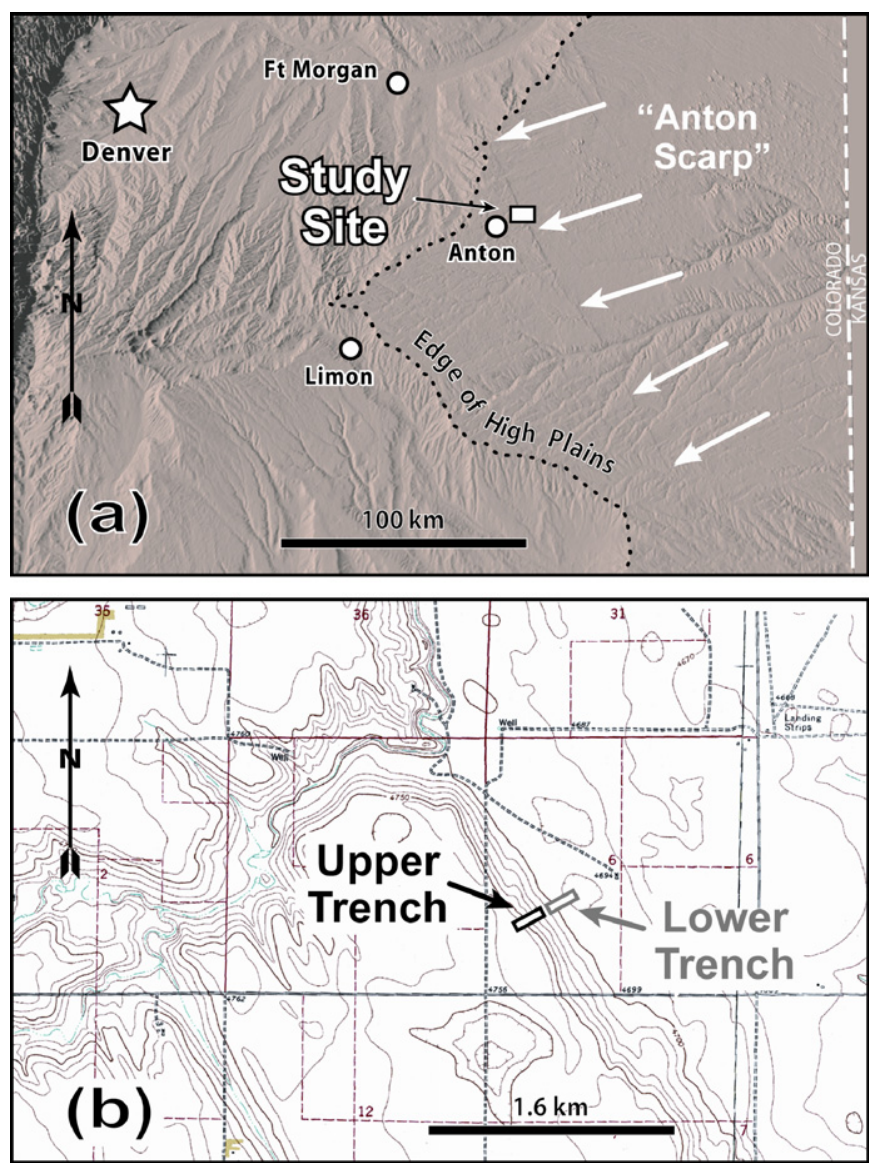

Fig. 1. (a) Map of the eastern border of Colorado, showing the lineament and trench locality near the town of Anton. Arrows indicate the approximate length of the lineament. (b) Topographic map showing a detailed view of the location of the Anton trenches. The upper trench is situated on the steepest part of the "scarp" and the future site of the lower trench is on the flatter toe of the lineament.
(V. Matthews, written communication). At the trench site, the lineament is $25 \mathrm{~m}$ high and the steeper, upper part is approximately $200 \mathrm{~m}$ wide with a maximum slope angle of $7^{\circ}$ (Noe, 2005). The lower part of the lineament is an additional $200 \mathrm{~m}$ wide with slope angles of $0-3^{\circ}$ (Wheeler, 2005). From the foot of the lineament, the valley floor contains gently rolling terrain that slopes northeastward at less than $1^{\circ}$. The $180 \mathrm{~m}$ long, upper trench extended from the lineament's crest down the fall line and was $4.5-6.0 \mathrm{~m}$ deep (Noe, 2005). Additional trenching investigations are being conducted in the lower part of the scarp face; this paper concerns only the results from the preliminary, upper trench (Fig. 1b).

The trench at Anton represents the second site in eastern Colorado to incorporate systematic and detailed luminescence and ${ }^{14} \mathrm{C}$ sampling in support of a paleoseismological investigation. An earlier study, conducted along the Cheraw fault, near Cheraw, Colorado, established three periods of rupture in the last $25 \mathrm{ka}$ (Crone et al., 1997).

Three samples were dated in this trench by thermoluminescence (TL). The upper eolian silt (loess?) yielded ages in the range 13-15 ka, while the upper part of a lower paludal silt was dated around $12-13 \mathrm{ka}$, with the base yielding ages of $18-21 \mathrm{ka}$. The lowest unit dated was a second paludal silt which appeared to be deposited between 18 and $25 \mathrm{ka}$. It is tempting to correlate some of these units with those seen in the Anton trench, but the paucity of other subsurface or trench data in eastern Colorado preclude this interpretation, although Crone et al. estimated surface-rupturing events at $8,12-13$, and $20-25 \mathrm{ka}$, with vertical offsets of 1.6 and $2.7 \mathrm{~m}$ for the last two events. Elsewhere in the area (Greeley, Fort Morgan, Wray, Sterling), Holocene eolian deposits have been widely sampled and correlated using TL and optically stimulated luminescence (OSL) dating (Madole, 1995; Clarke and Rendell, 2003; Madole et al., 2005), including dates for short-duration periods of eolian deposition adjacent to, and corresponding with possible drought indexes.

The depositional characteristics of loess and sand sheet units found in the Anton trench (Figs. 2a and b) have proven ideal for TL and OSL dating, indicating that their constituent mineral grains received sufficient sunlight to "zero" the luminescence signal. Less certain are OSL ages obtained from the calcic paleosols that occur in the basal trench deposits (Fig. 2a), although the original material (eolian sands) should have the same degree of bleaching as the upper loess packages.

\section{Trench stratigraphy}

The sedimentary record in the upper trench mainly consists of a sequence of loess, fluvial-eolian sand sheets and calcareous paleosols, all of which have been eroded by a series of gulley channels. Based on field observations and extensive trench mapping, these sequences were subdivided into U1 (lower calcareous paleosol and eolian sand), U2 (upper loess and sand), and U3 (the nested gulley or arroyo 

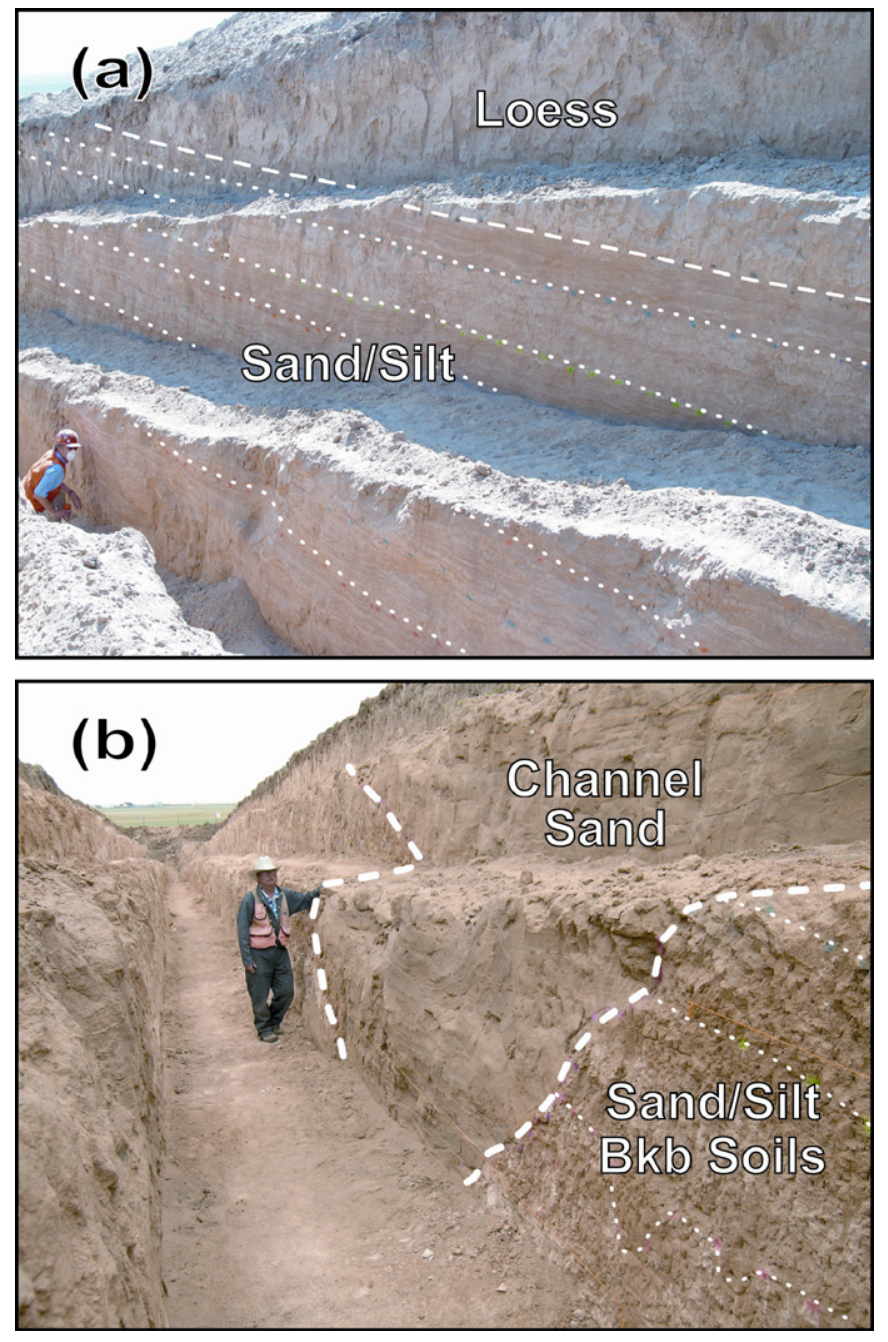

Fig. 2. (a) Photo showing characteristic loess and sandy silt units found in the upper unit of Anton upper trench (Unit 2 or U2), southeast wall. Dotted lines show distinct beds of finer or coarser-grained subunits with Unit 2. Bench heights approximately $1.5 \mathrm{~m}$, total thickness of trench from 4.5 to $6 \mathrm{~m}$. (b) Photo showing the nested arroyo channels (Unit 3 or U3) that formed within the sediments exposed at Anton Upper Trench, southeast wall. The sand and silt to the lower right of the picture make up the calcareous paleosols and eolian sands of the lower Unit 1 (U1). Bench height is approximately $1.50 \mathrm{~m}$ (note person for scale).

channel deposits) (Fig. 3). These nested channel deposits displayed trough cross-bedded sand and massive silty sand intervals, as well as intervals that were organic rich due to disseminated carbon, which gave the deposits a grayish color. The silt- and sand-filled gulley channels were as much as $5 \mathrm{~m}$ thick. No luminescence samples were taken from these channels.

Nearly all of the stratigraphic units exposed in the trench dip gently southwestward; those on the northeast-facing part of the lineament are truncated. The upper part of the exposed section (U2) consists of two massive to weakly bedded, slightly calcareous silt (loess) deposits. The upper loess deposit, which is beneath the crest of the lineament, is $4.5 \mathrm{~m}$ thick, and the lower loess deposit is $7.0 \mathrm{~m}$ thick. The two loess deposits are separated by $4.2 \mathrm{~m}$ of uniformly interbedded silt and sand layers that are $1-10 \mathrm{~cm}$ thick; these interbedded deposits are sheet sands (Fig. 3).

The lower part of the exposed stratigraphic section in the trench consists of a $2.5 \mathrm{~m}$ thick calcareous paleosol (U1), which is underlain by $4.5 \mathrm{~m}$ of mixed eolian sand dune and sheet sand deposits (Mahan et al., 2005). The bottommost exposed layer was a calcareous paleosol that consists of a clay-rich Bt horizon that had good soil structure and graded downward into a carbonate-rich Bk horizon (entire thickness not exposed). Based on the amount of reddening or rubification, the degree of cementation, and the degree of soil development in the paleosol, Wheeler (2005) estimated that this deposit's age somewhere between 200 and $300 \mathrm{ka}$. No evidence of faulting, fissuring, or bedding offset was found in this upper trench in spite of the detailed trench logging.

\section{Dating methodology and results}

\subsection{Sampling, preparation and analytical facilities}

There were no archeological artifacts or paleontological specimens recovered, either in situ or in the back dirt from the trench excavation. The samples taken for radiocarbon were accumulated woody deposits (not shells, carbonate stringers or delicate remains such as flowers, stems, or twigs) from within the nested gulley channels of U3 (Fig. 3); elsewhere in the trench only luminescence samples were taken. Five stratigraphic units were sampled for OSL, most by auguring into a freshly cleaned face of the southern trench wall and driving a polyvinyl chloride tube into the sediment. The ends of the tube were capped and shielded from sunlight. Two OSL samples were collected as large, intact blocks of indurated sediment (U1). The block samples were wrapped in aluminum foil and placed in a photography bag. Our sampling strategy consisted of taking the samples in well-bedded or well-defined stratigraphic units and included multiple sampling of $\mathrm{U} 1$ and $\mathrm{U} 2$ (Fig. 3) for a total of ten samples. Between 0.6 and $0.8 \mathrm{~kg}$ of sediment was taken from the OSL sampling sites for dosimetry and determination of present day and saturation moisture content.

Under subdued orange light in our laboratory, possible light-exposed end material from each block or tube $(\sim 3 \mathrm{~cm})$ was discarded. Samples were prepared for luminescence dating using standard procedures for hydrochloric acid $(4 \mathrm{~N} \mathrm{HCl})$, hydrogen peroxide $(35-50 \%)$, wet sieving, heavy liquids and hydrofluoric acid (50\%) (Millard and Maat, 1994; Roberts and Wintle, 2001; Singhvi et al., 2001; Mahan and Brown, 2007) in this order with appropriate modifications. The silt-sized grains were separated from the sand-sized grains during wet sieving and further processed to recover the $4-11 \mu \mathrm{m}$ grains using Stoke's law settling procedures.

To remove feldspars and to isolate pure quartz from the selected sand fraction, we centrifuged the sand sequentially in lithium sodium tungstate heavy liquid solutions with 


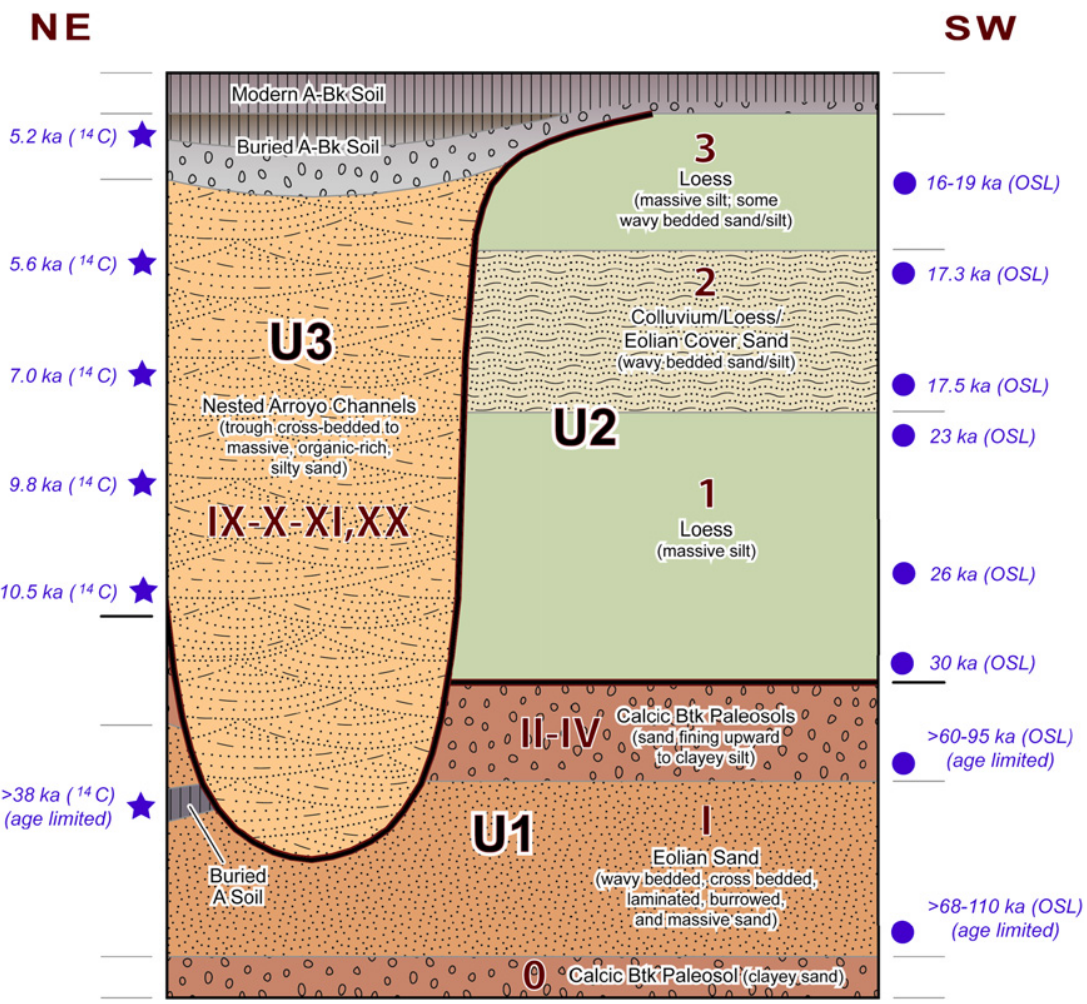

Fig. 3. Simplified drawing of the stratigraphic column exposed on the walls at Anton upper trench. The approximate location and age of the ${ }^{14} \mathrm{C}$ and $\mathrm{OSL}$ samples is indicated, with a star for the ${ }^{14} \mathrm{C}$ sites and a circle for the OSL sites. All ages are expressed as ka before AD 2004; the indicated ${ }^{14} \mathrm{C}$ age refers to the uncalibrated age. The reader is referred to Table 1 for sample ID and error limits on the OSL samples. The two duplicate samples for OSL are combined as one location and age.

densities of 2.58 and $2.69 \mathrm{~g} \mathrm{ml}^{-1}$. The float from 2.69 was subjected to a $50 \%$ solution of $\mathrm{HF}$ acid for $40 \mathrm{~min}$ while in an ultrasonic bath. After pouring off the HF solution, we put the sample in $6 \mathrm{~N} \mathrm{HCl}$ for 5 min while in an ultrasonic bath and finally re-sieved to winnow broken grains. For blue-light OSL, we affixed sand-size grains to the center of a 1-cm diameter steel disc with a light cover of Silicone spray. For infrared stimulated luminescence (IRSL), polymineral silt was evaporated from a methanol slurry, covering the entire disc.

Three types of luminescence dating were performed (OSL on quartz and potassium feldspars and TL). The OSL on quartz was obtained from fine-sand-sized quartz separates of $90-105 \mu \mathrm{m}$, although occasionally the $90-125 \mu \mathrm{m}$ sizes were used. IRSL-OSL to stimulate K-feldspar, was obtained on the 4-11 $\mu \mathrm{m}$ fine silt grains, and the TL analyses were performed on this same polymineral fine silt fraction $(4-11 \mu \mathrm{m})$. All were analyzed using continuous wave (CW-OSL) stimulation or linearly modulated temperature (TL).

All quartz grain samples were measured using the singlealiquot regenerated (SAR) dose procedure (Murray and Wintle, 2000; Banerjee et al., 2001), with a blue-light stimulation proceeded by an IRSL "wash" of $100 \mathrm{~s}$ at $60{ }^{\circ} \mathrm{C}$. Sample aliquot size was small for the SAR protocol, generally 200-250 grains, and centered in the middle of the disc. The sample size for the silt-sized particles was considerably larger, on the order of many thousands of grains (but no actual count was attempted), covering the entire disc surface. The fine-grained $(4-11 \mu \mathrm{m})$ polymineral sample splits from all 10 samples were analyzed using the total-bleach Multiple-Aliquot Additive-Dose (MAAD) method for both IRSL and TL (Singhvi et al., 1982; Lang, 1994; Richardson et al., 1997; Forman and Pierson, 2002). The TL was measured immediately after the IRSL by heating the same discs to $500{ }^{\circ} \mathrm{C}$. At least two equivalent dose measurements were made per IRSL sample to determine the ages using the MAAD protocol.

Anomalous fading tests on the stability of the IRSL signal were performed on three samples (AF-OSL-1USGS, AF-OSL-3USGS and AF-OSL-5JM) and indicated moderate to little signal instability (recording ratios of 0.93-0.90). These values are a ratio of luminescence emission after storage of 50 days divided by the immediate measurement (a ratio of 1.0 indicates stable luminescence), and we corrected to the " $g$ " factor of Huntley and Lamothe (2001) (Table 1) using their formulas in a simple worksheet. The IRSL ages agree well with available quartz age control, especially in the U2 stratigraphy, and seem to obviate the need for an extensive correction factor.

Luminescence measurements were performed using either a Risø TL-DA-15 or a Daybreak 1100 luminescence reader. Generally, IRSL and TL measurements were made on the Daybreak 1100 reader and the quartz blue-light 
Table 1

Feldspar infrared stimulated luminescence (IRSL) and quartz blue-light OSL ages from Anton upper trench

\begin{tabular}{|c|c|c|c|c|c|c|c|c|}
\hline $\begin{array}{l}\text { Sample information-lab } \\
\text { no.: stratum deepens }\end{array}$ & $\begin{array}{l}\text { Moisture } \\
(\%)\end{array}$ & $\begin{array}{l}\text { IRSL dose } \\
\text { rate }(\mathrm{Gy} / \mathrm{ka})\end{array}$ & $\begin{array}{l}\text { Equivalent } \\
\text { dose (Gy) }\end{array}$ & IRSL age (ka) & $n^{\mathrm{a}}$ & $\begin{array}{l}\text { Quartz dose } \\
\text { rate }(\mathrm{Gy} / \mathrm{ka})\end{array}$ & $\begin{array}{l}\text { Equivalent } \\
\text { dose (Gy) }\end{array}$ & $\begin{array}{l}\text { Quartz OSL } \\
\text { age (ka) }\end{array}$ \\
\hline $\begin{array}{l}\text { AF-OSL-1USGS } \\
\text { U2-upper massive loess }\end{array}$ & $5 \pm 1.5^{\mathrm{b}}$ & $4.58 \pm 0.10$ & $\begin{array}{l}73.0 \pm 1.28 \\
65.5 \pm 0.81\end{array}$ & $\begin{array}{l}19.8 \pm 1.09^{\mathrm{c}} \\
17.7 \pm 0.87^{\mathrm{c}}\end{array}$ & $37(40)$ & $3.23 \pm 0.07$ & $57.9 \pm 0.86$ & $17.9 \pm 0.92^{\mathrm{d}}$ \\
\hline $\begin{array}{l}\text { AF-OSL-2USGS } \\
\text { U2, duplicate }\end{array}$ & $5 \pm 1.5^{\mathrm{b}}$ & $4.58 \pm 0.10$ & $\begin{array}{l}55.3 \pm 0.93 \\
68.1 \pm 0.61\end{array}$ & $\begin{array}{l}14.9 \pm 0.81^{\mathrm{c}} \\
18.4 \pm 0.85^{\mathrm{c}}\end{array}$ & $21(25)$ & $3.23 \pm 0.07$ & $51.4 \pm 1.89$ & $15.9 \pm 1.35^{\mathrm{e}}$ \\
\hline $\begin{array}{l}\text { AF-OSL-3USGS } \\
\text { U2 colluvium or sheet sand }\end{array}$ & $4 \pm 1.0^{\mathrm{f}}$ & $5.73 \pm 0.15$ & $\begin{array}{l}73.7 \pm 1.22 \\
58.6 \pm 0.63\end{array}$ & $\begin{array}{l}17.9 \pm 1.14^{\mathrm{c}} \\
14.2 \pm 0.83^{\mathrm{c}}\end{array}$ & $34(40)$ & $3.80 \pm 0.10$ & $65.9 \pm 2.17$ & $17.4 \pm 1.46^{\mathrm{e}}$ \\
\hline $\begin{array}{l}\text { AF-OSL-4USGS } \\
\text { U2, bottom sheet sand }\end{array}$ & $2 \pm 0.5^{\mathrm{f}}$ & $4.84 \pm 0.13$ & $\begin{array}{l}64.8 \pm 2.49 \\
63.7 \pm 1.34\end{array}$ & $\begin{array}{l}19.8 \pm 1.23^{\mathrm{c}} \\
20.1 \pm 1.62^{\mathrm{c}}\end{array}$ & $26(29)$ & $3.39 \pm 0.09$ & $59.6 \pm 1.91$ & $17.6 \pm 1.42^{\mathrm{d}}$ \\
\hline $\begin{array}{l}\text { AF-OSL-2JM } \\
\text { U2, lower massive loess }\end{array}$ & $2 \pm 0.5^{\mathrm{b}}$ & $4.89 \pm 0.09$ & $\begin{array}{l}109 \pm 1.67 \\
-\end{array}$ & $22.4 \pm 1.06^{\mathrm{c}}$ & $29(32)$ & $3.27 \pm 0.05$ & $76.1 \pm 2.72$ & $23.4 \pm 1.90^{\mathrm{e}}$ \\
\hline $\begin{array}{l}\text { AF-OSL-3JM } \\
\text { U2, middle of lower loess }\end{array}$ & $2 \pm 0.5^{\mathrm{b}}$ & $4.69 \pm 0.08$ & - & $\begin{array}{l}- \\
-\end{array}$ & $16(20)$ & $3.08 \pm 0.05$ & $80.4 \pm 1.87$ & $26.1 \pm 1.47^{\mathrm{e}}$ \\
\hline $\begin{array}{l}\text { AF-OSL-5USGS } \\
\text { U2, bottom of lower loess }\end{array}$ & $10 \pm 1^{\mathrm{b}}$ & $4.60 \pm 0.09$ & $\begin{array}{l}124 \pm 3.42 \\
178 \pm 4.75\end{array}$ & $\begin{array}{l}27.0 \pm 1.85 \\
38.4 \pm 2.56\end{array}$ & $8(10)$ & $3.11 \pm 0.06$ & $92.0 \pm 6.80$ & $29.6 \pm 4.53^{\mathrm{d}}$ \\
\hline $\begin{array}{l}\text { AF-OSL-4JM } \\
\text { U2, bottom, duplicate }\end{array}$ & $6 \pm 1.5^{\mathrm{b}}$ & $4.59 \pm 0.07$ & $\begin{array}{l}126 \pm 2.34 \\
125 \pm 6.82\end{array}$ & $\begin{array}{l}27.5 \pm 1.35 \\
26.6 \pm 3.03(\mathrm{TL})\end{array}$ & $21(24)$ & $3.13 \pm 0.05$ & $98.7 \pm 3.20$ & $30.6 \pm 2.21^{\mathrm{d}}$ \\
\hline $\begin{array}{l}\text { AF-OSL-5JM } \\
\text { U1, bottom } \\
\text { Calcareous paleosols }\end{array}$ & $1 \pm 0.5^{\mathrm{b}}$ & $3.61 \pm 0.07$ & $\begin{array}{l}267 \pm 5.02 \\
226 \pm 3.72 \\
258 \pm 9.65\end{array}$ & $\begin{array}{r}101 \pm 11.5^{\mathrm{g}} \\
83.6 \pm 10.3^{\mathrm{g}} \\
94.5 \pm 11.0^{\mathrm{g}}\end{array}$ & $23(24)$ & $2.64 \pm 0.05$ & $157 \pm 5.28$ & $>59.5 \pm 4.65^{\mathrm{d}}$ \\
\hline $\begin{array}{l}\text { AF-OSL-6JM } \\
\text { U1, mixed eolian sand }\end{array}$ & $1 \pm 0.5^{\mathrm{f}}$ & $4.27 \pm 0.07$ & $\begin{array}{l}360 \pm 7.37 \\
262 \pm 7.57 \\
475 \pm 14.8\end{array}$ & $\begin{array}{r}>84.2 \pm 4.38 \\
>61.4 \pm 4.07 \\
\\
110 \pm 7.62(\mathrm{TL})\end{array}$ & $16(18)$ & $3.02 \pm 0.05$ & $205 \pm 10.1$ & $>67.9 \pm 7.10^{\mathrm{d}}$ \\
\hline
\end{tabular}

${ }^{a}$ Number of replicated equivalent dose $\left(D_{e}\right)$ estimates used. Figures in parentheses indicate total number of measurements made including failed runs with unusable data.

${ }^{\mathrm{b}}$ Field moisture, ages based on $25 \%$ moisture content through time as an average between field and saturation moisture values.

${ }^{\mathrm{c}}$ Silt fraction (4-11 $\mu \mathrm{m}$ size) for IRSL as multiple aliquot additive dose technique (MAAD), with correction of $g=3.94 \%$ fade/decade.

${ }^{\mathrm{d}}$ Lab used fine sand grains (125-150 $\mu \mathrm{m}$ size) for quartz OSL as single aliquot regeneration (SAR) technique. Quoted ages are to one sigma and do not include systematic errors.

${ }^{\mathrm{e}} \mathrm{Lab}$ used fine sand grains $(90-105 \mu \mathrm{m}$ size) for quartz OSL as single aliquot regeneration (SAR) technique. Quoted ages are to one sigma and do not include systematic errors.

${ }^{\mathrm{f}}$ Field moisture, ages based on $15 \%$ moisture content through time as an average between field and saturation moisture values.

${ }^{\mathrm{g}}$ Silt fraction $(4-11 \mu \mathrm{m}$ size) for IRSL as multiple aliquot additive dose technique (MAAD), with correction of $g=5.08 \%$ fade/decade.

Table 2

SAR quartz OSL measurement parameters

Instrument: RisøTL/OSL-DA-15A/B, Minisys 14

Stimulation source: four clusters LED, emission centered $470 \mathrm{~nm}$

Power delivered to aliquot: $22 \mathrm{~mW} / \mathrm{cm}^{2}$

Duration of stimulation: $40 \mathrm{~s}$

PMT: EMI 9236Q

Aliquot temp: $125^{\circ} \mathrm{C}$

Detection filters: 2 Hoya U-340

Preheat: $220-240{ }^{\circ} \mathrm{C} / 10$ s with same ${ }^{\circ} \mathrm{C}$ cut heat

Analytical procedures: IRSL 100 s wash; Bøtter-Jensen et al. (2000), Duller (2001)

OSL measurements were made on the Risø reader. The quartz OSL run parameters are given in Table 2, and IRSL and TL run parameters are given in Table 3 .

\subsection{Dosimetry}

Dosimetry measurements of potassium (K), uranium (U), and thorium (Th) were taken in situ, by using a portable Exploranium gamma-ray spectrometer for five of
Table 3

MAAD feldspar IRSL and TL measurement parameters

Instrument: Daybreak 1100 automated TL systems

Stimulation source: 30 IR diodes, emission centered on $880 \mathrm{~nm}$

Power delivered to aliquot: $19 \mathrm{~mW} / \mathrm{cm}^{2}$

Duration of stimulation: $100-30 \mathrm{~s}$

PMT: Thorn-EMI 9635Q

Aliquot temp: $30^{\circ} \mathrm{C}$

Detection filters: Schott BG-39 \& Kopp 7-59

Preheat: $124^{\circ} \mathrm{C} / 64 \mathrm{~h}$ or $140{ }^{\circ} \mathrm{C} / 6 \mathrm{~h}$

Analytical procedures: TLApplic 4.26 software

the sample sites (Table 4). The gamma-ray spectrometer provides the isotopic discrimination of gamma rays; correspondingly, beta and alpha dose rates may be estimated. At the five selected OSL sample locations, there were 2-3 $1000 \mathrm{~s}$ counts recorded (about $16.5 \mathrm{~min}$ ) from the portable gamma-ray spectrometer.

The in-situ data were compared with lab gamma ray counts obtained on the associated OSL sediments and from those collected for the other five samples (Table 4). For this 
Table 4

Comparative dosimetry from gamma spectrometry and neutron activation on samples from Anton upper trench

\begin{tabular}{|c|c|c|c|c|c|c|c|c|c|c|c|c|}
\hline Sample ID & K $(\%)$ & $\mathrm{U}(\mathrm{ppm})$ & Th (ppm) & $\begin{array}{l}\text { Elevation } \\
(\mathrm{m})\end{array}$ & $\begin{array}{l}\text { Depth } \\
(\mathrm{cm})\end{array}$ & $\begin{array}{l}\mathrm{H}_{2} \mathrm{O} \\
(\%)\end{array}$ & $\begin{array}{l}\text { IRSL/TL } \\
\operatorname{Dose}_{\mathrm{R}} \text { (Gy) }\end{array}$ & $\begin{array}{l}D_{\mathrm{R}} \text { for } \\
\mathrm{K}(\mathrm{Gy})\end{array}$ & $\begin{array}{l}D_{\mathrm{R}} \text { for } \\
\mathrm{U}(\mathrm{Gy})\end{array}$ & $\begin{array}{l}D_{\mathrm{R}} \text { for } \\
\text { Th }(\mathrm{Gy})\end{array}$ & $\begin{array}{l}D_{\mathrm{R}} \text { for } \\
\mathrm{Rb}(\mathrm{Gy})\end{array}$ & $\begin{array}{l}D_{\mathrm{R}} \text { for } \\
\text { cosmic ray } \\
(\mathrm{Gy})\end{array}$ \\
\hline $\begin{array}{l}\text { AF-OSL-1/2 } \\
\text { (gamma lab) }\end{array}$ & $2.13 \pm 0.02$ & $3.20 \pm 0.14$ & $11.4 \pm 0.38$ & 1452 & 226 & 25 & $4.58 \pm 0.09$ & 1.74 & 1.29 & 1.31 & 0.03 & 0.21 \\
\hline $\begin{array}{l}\text { AF-OSL-1/2 } \\
\text { (gamma field) }\end{array}$ & $2.12 \pm 0.09$ & $5.65 \pm 0.37$ & $9.36 \pm 0.42$ & 1452 & 226 & 25 & $5.33 \pm 0.24$ & 1.74 & 2.27 & 1.08 & 0.03 & 0.21 \\
\hline $\begin{array}{l}\text { AF-OSL-3 } \\
\text { (gamma lab) }\end{array}$ & $3.30 \pm 0.03$ & $4.80 \pm 0.28$ & $16.4 \pm 0.62$ & 1452 & 225 & 15 & $7.49 \pm 0.19$ & 2.98 & 2.15 & 2.10 & 0.06 & 0.21 \\
\hline $\begin{array}{l}\text { AF-OSL-3 } \\
\text { (gamma field) }\end{array}$ & $3.03 \pm 0.11$ & $2.35 \pm 0.15$ & $8.74 \pm 0.48$ & 1452 & 225 & 15 & $5.17 \pm 0.15$ & 2.74 & 1.05 & 1.12 & 0.05 & 0.21 \\
\hline $\begin{array}{l}\text { AF-OSL-3 } \\
\text { (INAA) }\end{array}$ & $2.26 \pm 0.04$ & $4.14 \pm 0.09$ & $12.4 \pm 0.10$ & 1452 & 225 & 15 & $5.73 \pm 0.17$ & 2.04 & 1.85 & 1.59 & 0.04 & 0.21 \\
\hline $\begin{array}{l}\text { AF-OSL-4 } \\
\text { (gamma lab) }\end{array}$ & $3.07 \pm 0.02$ & $2.84 \pm 0.16$ & $11.1 \pm 0.41$ & 1452 & 225 & 15 & $5.73 \pm 0.13$ & 2.77 & 1.27 & 1.42 & 0.05 & 0.21 \\
\hline $\begin{array}{l}\text { AF-OSL-4 } \\
\text { (gamma field) }\end{array}$ & $2.56 \pm 0.07$ & $3.19 \pm 0.21$ & $11.7 \pm 0.51$ & 1452 & 225 & 15 & $5.50 \pm 0.19$ & 2.31 & 1.43 & 1.50 & 0.04 & 0.21 \\
\hline $\begin{array}{l}\text { AF-OSL-4 } \\
\text { (INAA) }\end{array}$ & $2.30 \pm 0.04$ & $2.83 \pm 0.07$ & $9.72 \pm 0.09$ & 1452 & 225 & 15 & $4.84 \pm 0.10$ & 2.08 & 1.27 & 1.25 & 0.04 & 0.21 \\
\hline $\begin{array}{l}\text { AF-OSL-2JM } \\
\text { (gamma lab) }\end{array}$ & $2.28 \pm 0.02$ & $3.57 \pm 0.12$ & $12.8 \pm 0.28$ & 1452 & 1200 & 25 & $4.89 \pm 0.07$ & 1.87 & 1.44 & 1.48 & 0.03 & 0.07 \\
\hline $\begin{array}{l}\text { AF-OSL-3JM } \\
\text { (gamma lab) }\end{array}$ & $2.07 \pm 0.02$ & $3.51 \pm 0.12$ & $12.9 \pm 0.28$ & 1452 & 1500 & 25 & $4.69 \pm 0.07$ & 1.70 & 1.41 & 1.49 & 0.03 & 0.05 \\
\hline $\begin{array}{l}\text { AF-OSL-5 } \\
\text { (gamma lab) }\end{array}$ & $2.13 \pm 0.02$ & $3.16 \pm 0.13$ & $13.0 \pm 0.38$ & 1452 & 1400 & 25 & $4.60 \pm 0.09$ & 1.74 & 1.27 & 1.50 & 0.03 & 0.06 \\
\hline $\begin{array}{l}\text { AF-OSL-5 } \\
\text { (gamma field) }\end{array}$ & $2.85 \pm 0.09$ & $4.05 \pm 0.28$ & $9.96 \pm 0.49$ & 1452 & 1400 & 25 & $5.22 \pm 0.16$ & 2.33 & 1.63 & 1.15 & 0.04 & 0.06 \\
\hline $\begin{array}{l}\text { AF-OSL-4JM } \\
\text { (gamma lab) }\end{array}$ & $2.19 \pm 0.2$ & $3.01 \pm 0.10$ & $13.1 \pm 0.29$ & 1452 & 1660 & 25 & $4.59 \pm 0.07$ & 1.79 & 1.21 & 1.51 & 0.03 & 0.05 \\
\hline $\begin{array}{l}\text { AF-OSL-5JM } \\
\text { (gamma lab) }\end{array}$ & $2.19 \pm 0.02$ & $1.90 \pm 0.11$ & $8.52 \pm 0.26$ & 1452 & 2000 & 25 & $3.61 \pm 0.07$ & 1.79 & 0.76 & 0.98 & 0.03 & 0.04 \\
\hline $\begin{array}{l}\text { AF-OSL-6JM } \\
\text { (gamma lab) }\end{array}$ & $2.32 \pm 0.03$ & $2.49 \pm 0.09$ & $11.2 \pm 0.27$ & 1452 & 2180 & 15 & $4.27 \pm 0.06$ & 1.90 & 1.00 & 1.30 & 0.04 & 0.03 \\
\hline
\end{tabular}

purpose, the bulk samples were dried, homogenized by gentle disaggregation, weighed, sealed in plastic planchets having a diameter of $15.2 \mathrm{~cm} \times 3.8 \mathrm{~cm}$ (some modification from Murray et al., 1987), and then immediately placed in a gamma-ray spectrometer for about $8.5 \mathrm{~h}$. Samples were then stored for a minimum of 21 days to allow radon to achieve radioactive equilibrium, and the measurements were repeated. The fraction of radon emanation was estimated from the difference of these two spectrometer measurements. A sealed/unsealed ratio of $<1.10$ is not considered to represent significant radon escape under laboratory conditions. These count rates are accurate for calculating dose rates (Aitken, 1985, 1998; Snyder and Duval, 2003). For all but one sample, the range of ratio change was $0.91-1.15$.

Two samples were analyzed by instrumental neutron activation analyses (INAA) as a way to provide more detailed checks on any possible disequilibrium in the $U$ and Th decay chain. Full details of this technique are described in Budahn and Wandless (2002). No substantial differences were noted (Table 4). Where differences were noted between the analytical elemental concentration techniques (gamma lab, gamma in situ, and INAA), the dose rate chosen for age calculations came from the largest available body of data that had the most controllable parameters (usually the gamma lab analyses, sometimes the INAA). This was deemed more accurate than simply averaging the accumulated dose rates.

Dose rates are listed for IRSL and TL (Table 4), for the corresponding value that was used in the quartz OSL dose rates, the alpha component, as well as about $10 \%$ of the beta component, must be subtracted, due to the hydrofluoric etch performed on the quartz grains before they were analyzed for OSL. Cosmic-ray dose rate was estimated for each sample as a function of depth, elevation above sea level, and geomagnetic latitude (Prescott and Hutton, 1988) and all contributions to the dose rate were corrected for the effect of moisture. Measured elemental concentrations, associated dose rates, and cosmic ray contributions are shown (Table 4). Alpha and beta contributions to the dose rate were corrected for grain-size attenuation (Aitken, 1985). The alpha efficiency for the silt-sized samples was determined by comparing MAAD-alpha source exposed and MAADbeta source exposed curves, using approaches in Aitken (1985). 
When these samples were collected the trench had been open to intense summer heat for 2-3 months, thus artificially drying out the sediment. Earlier winter precipitation would have been more than enough to percolate through the sediment, as noted in the wetter natural outcrops along the scarp, wetting it to a more normal $10-15 \%$ moisture value. Dose rates were calculated assuming a $15-25 \%$ moisture value (based on how finegrained the sample unit was), as a reasonable average between field (1-5\%) and saturation moisture (no units were greater than $40-45 \%$ ). No samples were assumed to have been at full saturation during their entire depositional history when determining the appropriate dosimetry.

\subsection{Luminescence characteristics and equivalent doses}

The growth of the luminescence with increasing dose was represented well by a single saturating exponential and linear function and illustrates the generally reliable behavior of the quartz samples for the SAR protocol. Comparisons of the equivalent doses obtained on both the quartz and the feldspar indicate that the MAAD procedure also returned reliable, if less precise ages. For each aliquot that was measured, the complete growth curve was constructed based on the measurement of three regenerative doses $(2 \times$ the natural). The response to a zero dose was also measured to see whether the growth curve passes through the origin. To verify if the sensitivity correction works well, a second measurement of the response to the lowest regenerative dose was also made (a recycling ratio). Recycling ratios between 0.92 and 1.11 were accepted for the SAR protocol (except for the older sample ratios which deteriorated). The accepted ratios from the older samples were fixed at a more tolerant $0.84-1.17$ to allow more aliquots to be accepted without sacrificing additional machine time. This recycling ratio change could possibly due to the suspected presence of a stronger medium to slow component (although subtracting the early background did not improve the ratios) or due to the increasing calcic alteration within the paleosol.

Representative dose recovery data for three samples are shown in Fig. 4 (quartz only). Dose recovery tests were also performed to ensure that the sediments were responsive to optical techniques and that the proper preheat temperatures were used in producing the equivalent dose $\left(D_{\mathrm{e}}\right)$ values (Murray and Wintle, 2003; Roberts, 2006). Using four aliquots per sample, a range of preheat temperatures from 180 to $300{ }^{\circ} \mathrm{C}$ (at $10 \mathrm{~s}$ ). The dose recovery tests were performed on unheated material and known doses were given to the samples that generally approximated their natural equivalent dose values (Roberts, 2006). Sample AF-1USGS was given doses of $50 \mathrm{~Gy}$, sample AF-2JM was given doses of $70 \mathrm{~Gy}$, and sample AF-5JM was given doses of $100 \mathrm{~Gy}$ from a calibrated beta source attached to the Risø TL-DA-15. Samples were bleached similar to procedure suggested in Roberts (2006) and Roberts et al. (2007). The dose recovery data are shown in Fig. 4. All samples showed ability to recover a known laboratory radiation dose across the range of preheats shown; although AF-5JM underestimates some of the doses at lower preheat temperatures.

All sample aliquots were then run at either $240{ }^{\circ} \mathrm{C}$ for $10 \mathrm{~s}$ or $220^{\circ} \mathrm{C}$ for $10 \mathrm{~s}$, depending on the initial estimate of age. A slightly stronger preheat was chosen for older age samples. At least 20 aliquots were run per sample, except for AF-OSL-5USGS, which had inadequate quartz

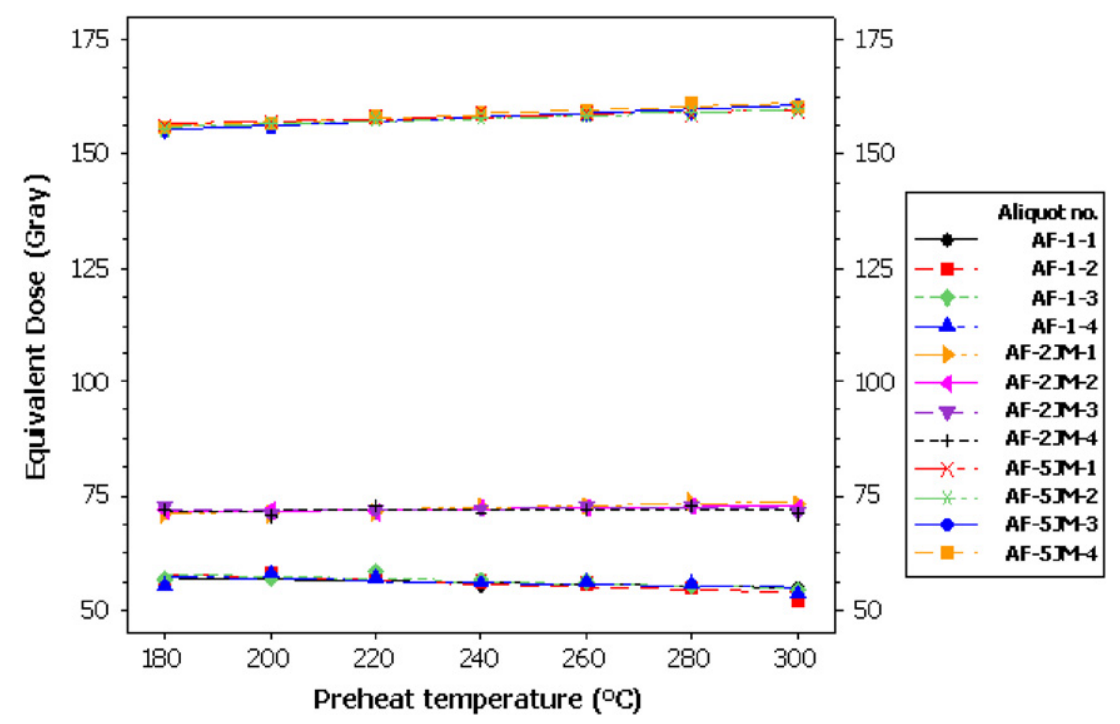

Fig. 4. Preheat plots showing equivalent dose values obtained for various preheat temperatures for samples AF-1, AF-2JM, and AF-5JM, located at the top, middle, and bottom of the trench, respectively. The values shown are the mean of four aliquots with a regression line connecting the groups. The biggest equivalent dose values (AF-5JM), show a slight increase with temperature, the middle equivalent dose values (AF-2JM) show no change and the smallest equivalent dose values (AF-1) show a slight decrease with temperature. 
recovery. The averaged equivalent dose values are summarized in Table 1.

\subsection{Dose distributions (blue-light OSL only)}

The distribution of equivalent doses from the SAR analyses is shown in Figs. 5a-c (duplicates included). An examination of the individual value plots shows more dispersion than expected for loess samples, with only a few samples showing a very tight distribution. The histograms were constructed in such a way as to allow the closest possible bin width to match the sample standard deviation. It was not always possible to accurately plot multiple histograms in this way. The well-preserved bedding structures and general lack of burrows (see Sections 2 and 4) are indicative of nonbioturbated sediments (U2). As histograms do not take into account the difference in precision by which each value is determined, a decay curve and a radial plot are included, depicting equivalent doses obtained on the upper loess of U2 (Figs. 6a and b). This plot will illustrate why a weighted mean was chosen to obtain the final equivalent doses and why the behavior of AF-OSL-1USGS (upper loess in U2) is considered a good approximation for the behavior observed in the other nine OSL samples.

All samples show slightly positively skewed data (except the older samples in U1) with standard deviations (Figs. $5 \mathrm{a}-\mathrm{c}$ ) from $16 \%$ to $26 \%$, with an average of $20 \%$. We did not carry out tests to distinguish whether the causes of the scatter were related to poor luminescence reader precision, instrumental uncertainties from other laboratory measurements, or geological origin and characteristics of the minerals we were dating. Any outliers at the high-end dose of the distribution we attribute to the presence of a small population of incompletely reset grains and outliers at the low-end dose to unrecognized bioturbation.

\section{Stratigraphic unit ages and discussion}

\subsection{Luminescence ages}

On two separate occasions, 10 luminescence samples (including two duplicates) were collected, all from the U1 or U2 sections of Anton Upper Trench (Fig. 3). Table 1 summarizes the information relevant to the age and uncertainty calculations. For the sake of clarity, ages

\section{a Unit 2 Histograms-upper loess and sand sheet} normal dstribution ane shown over histograms

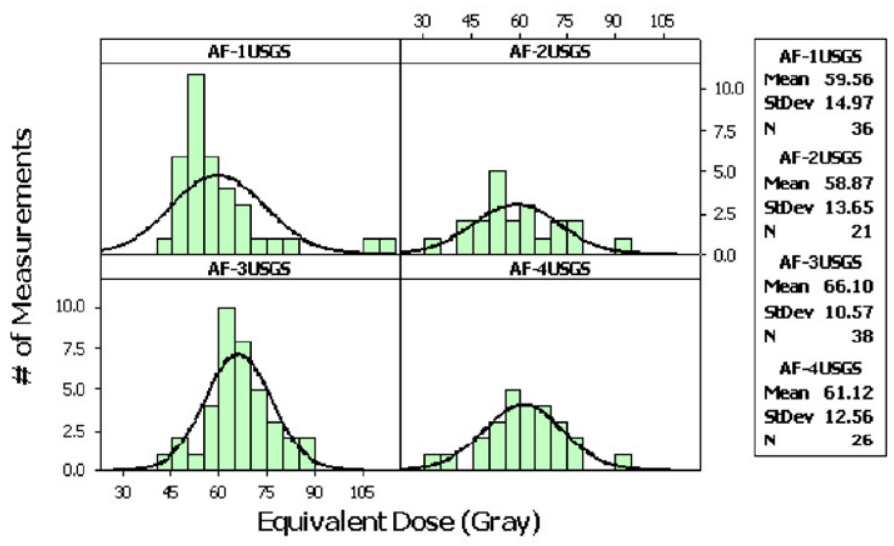

b Unit 2 histograms lower loess Normal dstibution ane shown over fistogams

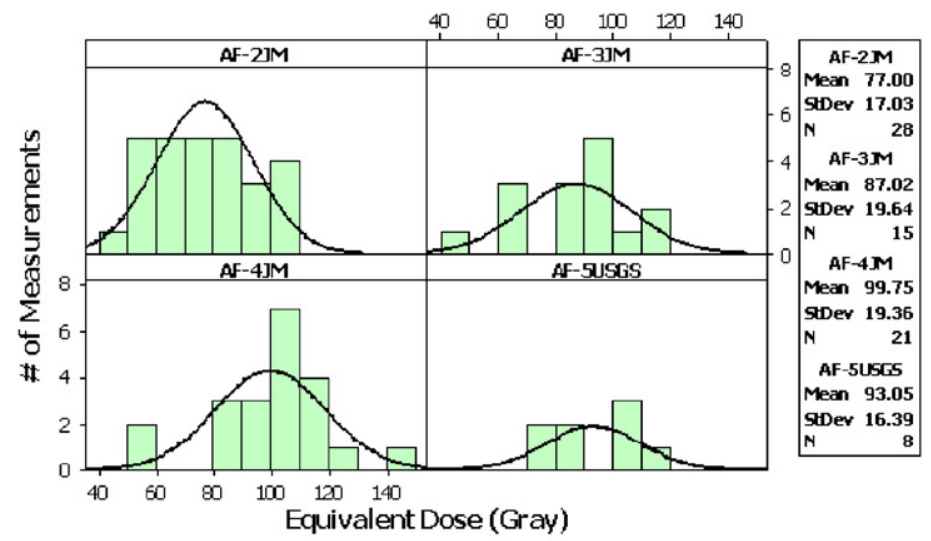

C

Unit 1 Histograms

normal Dstibution ane shown over histograms

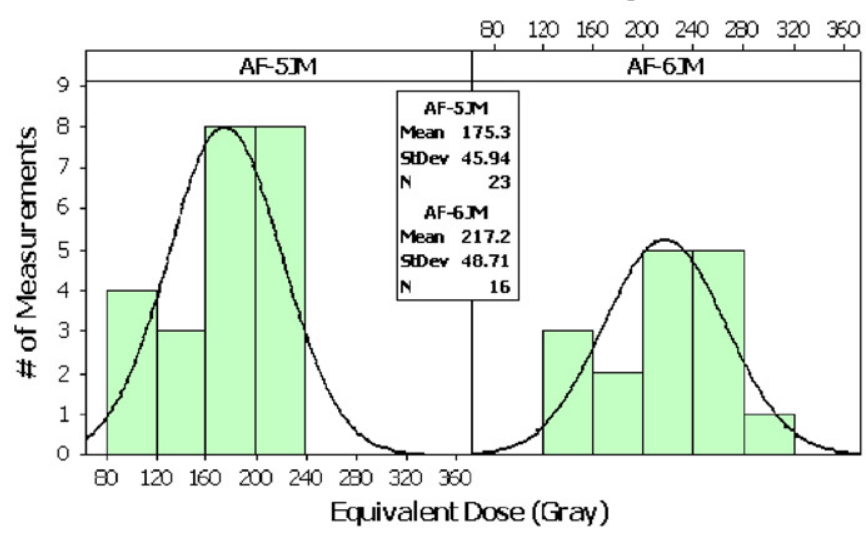

Fig. 5. Comparisons of equivalent dose distributions from (a) samples collected in the upper loess and sand sheet within U2 (samples AF-1USGS and AF2USGS are duplicates, from the same stratigraphic layer), (b) samples in the lower loess within U2 (samples AF-4JM and AF-5USGS are duplicates, from the same stratigraphic layer), and (c) samples in the lowest units of U1. 


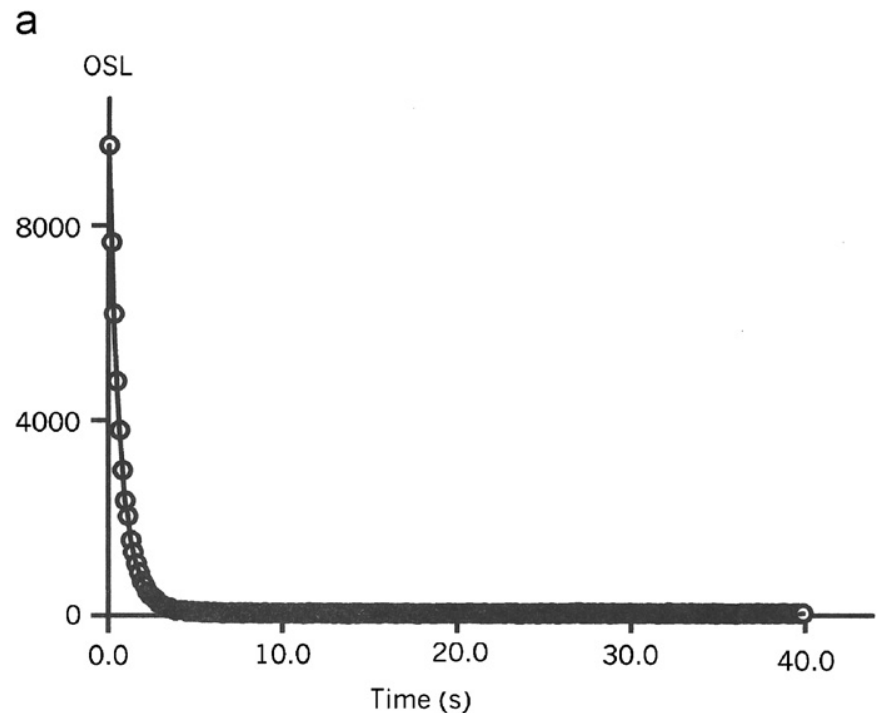

b
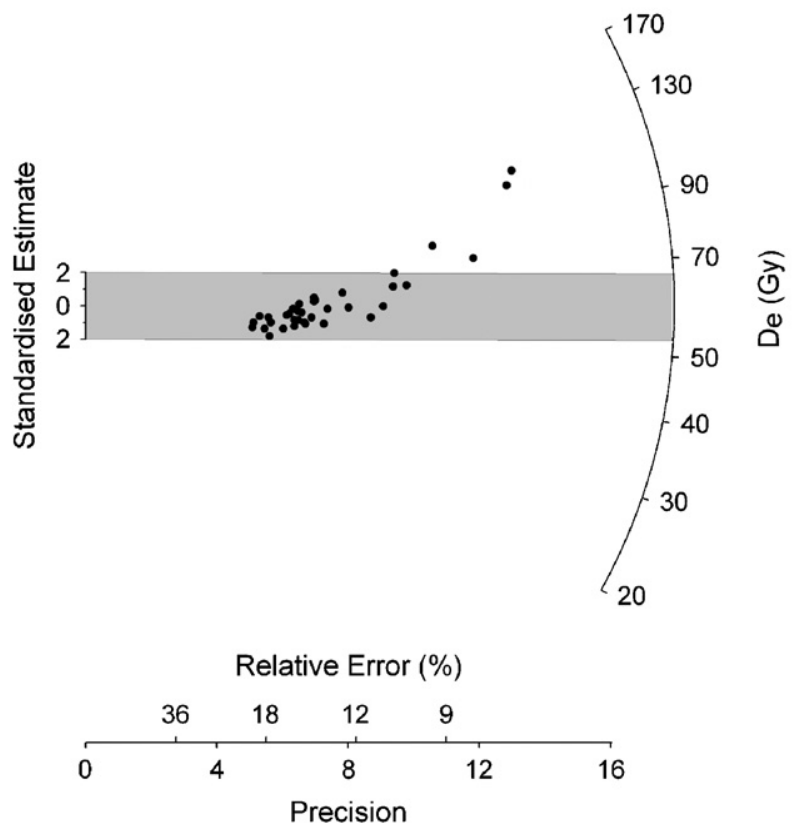

Fig. 6. (a) Example of a continuous wave OSL decay curve from sample AF-OSL-1USGS, showing the characteristic clean quartz signal encountered in most of the samples. $X$-axis is time of LED stimulation in counts/ $0.16 \mathrm{~s}$. (b) Radial plot showing the distribution of equivalent dose values for 36 SAR aliquots of quartz from AF-OSL-1USGS. Precision increases to the right and the band in the middle shows a standardized estimate of the equivalent dose (at $59.6 \mathrm{~Gy}$ ) within two sigma. The two outliers are also visible in Fig. 5a.

contained within the stratigraphic column, trench logs and this discussion are those from the quartz OSL. In general, the IRSL and TL ages are equal to or older than the quartz OSL ages (except for AF-OSL-4JM in the calcareous paleosol of U1) and show good general agreement and overlap until deeper sediments are dated. The dating methodology for IRSL and TL MAAD is known to be inherently limited in both terms of precision and accuracy. For a more detailed discussion of this statement, see
Murray and Wintle (2000), Bøtter-Jensen et al. (2003), and Wintle and Murray (2006).

The additional inclusion of analyses obtained by using IRSL and TL allows us to undertake a direct comparison with previous work (Crone et al., 1997; Madole et al., 2005), as well as providing an overlap with the newer quartz OSL techniques, which will be used in future trench investigations. While there were some anomalous fading problems that were not fully investigated, as noted in Section 3.1, and are partially responsible for some of the IRSL age outliers noted in three samples (AF-OSL2USGS, AF-OSL-3USGS and AF-OSL-4JM) these problems are not serious enough to consider the ages as suspect. Moreover, the fact that the IRSL analyses are in relative age concordance with the quartz OSL strengthens our assertion that there was no significant disequilibrium in the dosimetry.

The quartz OSL ages obtained on the upper massive loess of U2 are around 15.9-17.9 ka. The duplicate samples are in age agreement when associated errors are used to calculate the range $(17.9 \pm 0.92$ and $15.9 \pm 1.35 \mathrm{ka})$. These ages coincide well with those reported in other recent studies on the Peoria Loess (14-16 ka for the upper Peoria and $18-25 \mathrm{ka}$ for the Peoria base in Nebraska) (Bettis et al., 2003; Roberts et al., 2003), with the distal areas (like eastern Colorado) recording loess accumulation later than sources located close to major loess sources (Roberts et al., 2007). The lower massive loess unit of U2 returned luminescence ages of $23.4-30.6 \mathrm{ka}$. These results indicate the upper loess unit is likely Peoria Loess and the lower loess is either Peoria Loess base (indicating a beginning of deposition that matches other studies, Roberts et al., 2007) or more likely the Peoria Loess begins to grade into the Gilman Canyon Formation, which has been reported with ${ }^{14} \mathrm{C}$ ages ranging from 20 to $40 \mathrm{ka}$ in Nebraska and Kansas (Bettis et al., 2003; Roberts et al., 2003). Although the Gilman Canyon Formation typically has an organic-rich soil developed in it (Bettis et al., 2003), we did not find such a soil at the Anton Upper Trench site. We also did not find the Brady Soil above the Peoria Loess layers, as would commonly be expected. The Brady Soil is dated to $10-12 \mathrm{ka}$ with ${ }^{14} \mathrm{C}$ and thus cannot be the buried soil found above the nested gulley deposits of U3 (Fig. 3).

The intervening eolian sheet sand contained between the upper loess packages is tightly constrained in age at $17.3-17.5 \mathrm{ka}$ and shows much coarser particle size (Section 2). This sand layer is $4 \mathrm{~m}$ thick and indicates an increased coarser-grained supply from either glaciogenic or glacio-fluvial sources. It contains somewhat lumpy, wavy bedding planes similar to those which would be deposited atop ice and snow and redeposited locally upon melting of the ice or snow. Alternatively, this unit could consist of thin layers of wind-reworked colluvium, although there is no nearby or obvious source for the colluvium.

It seems more logical that this layer reflects the coarsestgrained zone of three zones in the Peoria Loess as identified by Muhs and Bettis (2003) in Iowa. They concluded that 
there was slow accumulation of loess, followed by rapid accumulation of coarse-grained glaciogenic-source loess which concluded with finer-grained glaciogenic loess. Glacial outwash is a candidate for a loess source in eastern Colorado, as is the White River Group and sediments from the Proterozoic Front range rocks (Aleinikoff et al., 1998).

Particle size analyses of the sediment from three subunits contained in U2 confirm the presence of coarser-grained material in the middle subunit. The analyses for the uppermost massive loess showed $19.4 \%$ sand, $74 \%$ silt, and $6.6 \%$ clay (where sand is $2000-50 \mu \mathrm{m}$, silt is $50-2 \mu \mathrm{m}$, and clay is $<2 \mu \mathrm{m})$. The middle sheet sand layer has $37.5 \%$ sand, $57.2 \%$ silt, and $5.3 \%$ clay. The lower massive loess has $14.4 \%$ sand, $77.0 \%$ silt, and $8.6 \%$ clay, remarkably similar to the upper loess. In the lowest U1, the upper calcareous paleosol was much sandier than anything in U1, with particle size analyses of $58.9 \%$ sand, $37.1 \%$ silt, and $4.1 \%$ clay. The deepest eolian sand subunit has analyses of $72.7 \%$ sand, $24.2 \%$ silt, and $3.0 \%$ clay.

The OSL ages are much older in the calcareous paleosols and mixed eolian sand of U1. The sample that was taken from the oldest widespread eolian-sand deposit (Fig. 3) near the bottom of the trench, showed saturation characteristics for both IRSL and quartz OSL. It is uncertain whether the TL is also an underestimation, as it recorded a stable plateau and fit to saturating exponential function. However, it is likely that all the luminescence ages generated from this unit are an underestimation, even the $110 \mathrm{ka}$ as dated by TL ( $>67.9 \mathrm{ka}$ by OSL), because the degree of original surface modification and strong relict soil development suggests that the deposits are middle Pleistocene.

If we speculate briefly on the character of these deposits, there appears to be a correlation between the older Loveland Loess and the mixed eolian sand subunit of U1. The Loveland Loess is overlain by at least two younger loess layers (Roberts et al., 2007) and has a soil developed in the upper part, called the Sangamon "Geosol". The Sangamon geosol is a prominent, thick paleosol, generally accepted to have formed around $120 \mathrm{ka}$ (Bettis et al., 2003); it is impossible to tell from the ages obtained by our OSL dating, whether any of the calcareous paleosols in Anton upper trench can be correlated to the Sangamon. It is tempting to think that one of the bottom calcareous paleosols could be Sangamon, but more detailed sample work needs to be done to rigorously experiment with the quartz OSL age underestimates seen in sediments of $\mathrm{U} 1$.

\section{2. ${ }^{14} \mathrm{C}$ ages}

The development of the nested gulley channels is revealed only by six ${ }^{14} \mathrm{C}$ ages on woody material, as no luminescence samples were collected from this unit (U3) and thus no direct comparison between ${ }^{14} \mathrm{C}$ and OSL data can be made, although all luminescence ages from the eroded units are older than the inset channels.
These channels were cut into the scarp face between approximately $12,390 \pm 520$ and $5790 \pm 30$ cal years BP ago (uncalibrated ages of 5.2 and $10.5 \mathrm{ka}$ are shown in Fig. 3). Modern soil processes then dominated, as the trench is topped by a buried A-Ck soil dated at $5790 \pm 30$ cal years $\mathrm{BP}$ ago (shown uncalibrated as $5.2 \mathrm{ka}$ in Fig. 3). The oldest ${ }^{14} \mathrm{C}$ dates come from the stratigraphically youngest channels, based on cross-cutting relationships $(11,230 \pm 50$ and $12,390 \pm 520$ cal years BP). This apparent anomaly may be explained if the gulley system was eroding into progressively older organic paleosols in an upstream area. The ages would therefore reflect the ages of the strata being eroded (i.e., late Pleistocene to early Holocene), and not the ages of the channels or the channel fill.

The ages of the channels are probably not older than $6410 \pm 100$ cal years BP (shown as $5.6 \mathrm{ka}$ in Fig. 3), based on the ages of the carbon in the channel fill. The importance of these gulley deposits is that they are topographically lower than the youngest loess deposit (16 ka using OSL). This relationship, and the associated dates, may constrain the formation of the scarp face. Erosion and down cutting of the loess and older strata in the incipient scarp face occurred less than $16 \mathrm{ka}$, culminating at about $5.7 \mathrm{ka}$ by the cutting of gulley channels in the mid-scarp face.

\section{Conclusions}

Through luminescence dating, we have established a timeframe for the deposition of several Quaternary stratigraphic units and the development of the erosional face of a large escarpment that crosses Colorado's High Plains, and have added to the overall knowledge of absolute age chronologies in eastern Colorado. Luminescence dating was carried out following a robust dating methodology involving the use of three different kinds of luminescence. The luminescence characteristics for the samples are satisfactory, as indicated by the ability of the samples to recover a known dose. Small aliquot samples analyses and general agreement of age techniques show that most of the material dated was well-bleached at deposition.

From optical dating we conclude the upper loess unit (U2) is correlated to Peoria Loess, the lower loess unit (U1) is correlated to either the Peoria or the Gilman Canyon Formation, and the intervening sand interval may represent a period of increased glaciogenic activity. The age of the lowest eolian and calcic paleosol units within the trench remain speculative, but are certainly greater than $100 \mathrm{ka}$ in age and may be the Sangamon "Geosol". Using OSL and ${ }^{14} \mathrm{C}$ dating, we conclude that the scarp face formed between 16 and $5.7 \mathrm{ka}$ as an erosional feature, concluding with a series of gulleys cutting across the mid-scarp face.

Although there is no definitive evidence for a seismogenic origin to the escarpment lineament based on the findings from the upper trench, more trenching is being done lower on the scarp face, along with OSL dating on 
samples from that trench. The results from this prelimininary study will be useful for comparing the stratigraphy in the upper and lower parts of the scarp face, and will ultimately be of use in determining the cause and evolution of this geomorphic feature.

The present study illustrates that luminescence dating continues to be a powerful tool for establishing a chronological framework for paleoseismology investigations. Our work also illustrates the limitations imposed by saturation of the fast component of OSL and variations in the accuracy and precision of optical dating. In this respect, we clearly demonstrate the value of dating multiple samples from the same level and from a well-defined vertical stratigraphic relationship.

\section{Acknowledgements}

We would like to thank Rich Madole, Larry Benson, Deborah Green, Alan Jones, and Serin Duplantis for valuable field assistance and advice. We also thank Kathryn Liles and Becky Ferega for technical help with the laboratory analyses. Discussions with Anthony Crone (USGS), Vince Matthews (CGS), Emily Taylor (USGS) and Rus Wheeler (USGS) clarified ideas presented in this paper, although interpretations and conclusions are strictly the responsibility of the authors.

\section{References}

Aitken, M.J., 1985. Thermoluminescence Dating. Academic Press, London, 359pp.

Aitken, M.J., 1998. An Introduction to Optical Dating. Oxford University Press, Oxford, 267pp.

Aleinikoff, J.N., Muhs, D.R., Fanning, C.M., 1998. Isotopic evidence for the sources of late Wisconsin (Peoria) loess, Colorado and Nebraska: implications for paleoclimate. In: Busacca, A.J. (Ed.), Dust Aerosols, Loess Soils and Global Change. Washington State University College of Agriculture and Home Economics, Miscellaneous publication no. MISC0190, Pullman, pp. 124-127.

Banerjee, D., Murray, A.S., Bøtter-Jensen, L., Lang, A., 2001. Equivalent dose estimation using a single aliquot of polymineral fine grains. Radiation Measurements 33 (1), 73-94.

Bettis, A.E., Muhs, D.R., Roberts, H.M., Wintle, A.G., 2003. Last Glacial loess in the conterminous USA. Quaternary Science Reviews 22, 1907-1946.

Bøtter-Jensen, L., Bulur, E., Duller, G.A.T., Murray, A.S., 2000. Advances in luminescence instrument systems. Radiation Measurements 32, 523-528.

Bøtter-Jensen, L., McKeever, S.W.S., Wintle, A.G., 2003. Optically Stimulated Luminescence Dosimetry. Elsevier, Amsterdam, 355pp.

Budahn, J.R., Wandless, G.A., 2002. Instrumental neutron activation by abbreviated count. 02-223, US Geological Survey.

Clarke, M.L., Rendell, H.M., 2003. Late Holocene dune accretion and episodes of persistent drought in the Great Plains of northeastern Colorado. Quaternary Science Reviews 22, 1051-1058.

Colorado State University, January 5, 2007, Precipitation: Colorado Water Knowledge, 〈http://waterknowledge.colostate.edu/precip.htm $\rangle$. Accessed February 5, 2007.

Crone, A.J., Machette, M.N., Bradley, L.A., Mahan, S.A., 1997. Late Quaternary surface faulting on the Cheraw fault, southeastern Colorado: US Geological Survey Geological Investigations Map I-2591.
Duller, G.A.T., 2001. Equivalent dose determination using single aliquots. Nuclear Tracks and Radiation Measurements 18, 371-378.

Forman, S.L., Pierson, J., 2002. Late Pleistocene luminescence chronology of loess deposition in the Missouri and Mississippi river valleys, United States. Paleogeography, Paleoclimatology, Paleoecology 186 (1-2), 25-46.

Huntley, D.J., Lamothe, M., 2001. Ubiquity of anomalous fading in $\mathrm{K}$-feldspars and the measurement and correction for it in optical dating. Canadian Journal of Earth Sciences 38, 1093-1106.

Lang, A., 1994. Infrared stimulated luminescence dating of Holocene reworked silty sediments. Quaternary Science Reviews 13 (5-7), 525-528.

Madole, R.F., 1995. Spatial and temporal patterns of late Quaternary eolian deposition, eastern Colorado, USA. Quaternary Science Reviews 14, 155-177.

Madole, R.F., VanSistine, D.P., Michael, J.A., 2005. Distribution of Late Quaternary wind-deposited sand in eastern Colorado. US Geological Survey Scientific Investigations Map 2875.

Mahan, S.A., Brown, D.J., 2007. An optical age chronology of Late Quaternary extreme fluvial events recorded in Ugandan dambo soils. Quaternary Geochronology 2 (1-4), 174-180.

Mahan, S.A., Noe, D.C., McCalpin, J.P., Madole, R., 2005. Optically stimulated luminescence dating of loess and sand sheets in the Anton scarp trench, northeast Colorado. Geological Society of America Abstracts with Programs 37 (6), 14.

Matthews III, V., 2004. Neogene faulting in Colorado's High Plains. Geological Society of America Abstracts with Programs 36 (5), 117.

McCalpin, J.P. (Ed.), 1996. Paleoseismology. Academic Press, San Diego, 588pp.

McGovern, E.H., 1964. Geology and ground-water resources of Washington County, Colorado. US Geological Survey Water-Supply Paper 1777, 46pp., 4 pls., scale 1:125,000.

Millard, H.T., Maat, P.B., 1994. Thermoluminescence dating procedures in use at the US Geological Survey, Denver, Colorado. US Geological Survey Open-File Report 94-249, 112pp.

Muhs, D.R., Bettis, A.E., 2003. Quaternary loess-paleosol sequences as examples of climate-driven sedimentary extremes. Geological Society of America Special Paper 370, 53-74.

Murray, A.S., Wintle, A.G., 2000. Luminescence dating of quartz using an improved single-aliquot regenerative-dose protocol. Radiation Measurements 32 (1), 57-73.

Murray, A.S., Wintle, A.G., 2003. The single aliquot regenerative dose protocol: potential for improvements in reliability. Radiation Measurements 37, 377-381.

Murray, A.S., Marten, R., Johnston, A., Martin, P., 1987. Analysis for naturally occurring radionuclides at environmental concentrations by gamma spectrometry. Journal of Radioanalytical and Nuclear Chemistry Article 15, 263-288.

Noe, D.C., 2005. Investigations of possible Quaternary faulting on Colorado's High Plains - what is the origin of the Anton scarp? Geological Society of America Abstracts with Programs 37 (6), 14.

Prescott, J.R., Hutton, J.T., 1988. Cosmic ray and gamma ray dosimetry for TL and ESR. Nuclear Tracks and Radiation Measurements 14, 223-230.

Richardson, C.A., McDonald, E.V., Busacca, A.J., 1997. Luminescence dating of loess from the northwest United States. Quaternary Science Reviews 16 (3-5), 403-415.

Roberts, H.M., 2006. Optical dating of coarse-silt sized quartz from loess: evaluation of equivalent dose determinations and SAR procedural checks. Radiation Measurements 41, 923-929.

Roberts, H.M., Wintle, A.G., 2001. Equivalent dose determinations for polymineralic fine-grains using the SAR protocol-application to a Holocene sequence of the Chinese Loess Plateau. Quaternary Science Reviews 20 (5-9), 859-863.

Roberts, H.M., Muhs, D.R., Wintle, A.G., Duller, G.A.T., Bettis, A.E., 2003. Unprecendented last-glacial mass accumulation rates determined by luminescence dating of loess from western Nebraska. Quaternary Research 59, 411-419. 
Roberts, H.M., Muhs, D.R., Bettis III, E.A., 2007. Loess records of North America. In: Elias, S.A. (Ed.), Encyclopedia of Quaternary Science, vol. 2 of 4. Elsevier B.V., Oxford, pp. 1456-1466.

Singhvi, A.K., Sharma, Y.P., Agrawal, D.P., 1982. Thermo-luminescence dating of sand dunes in Rajasthan, India. Nature 295 (5847), 313-315.

Singhvi, A.K., Bluszcz, A., Bateman, M.D., Rao, M.S., 2001. Luminescence dating of loess-palaeosol sequences and coversands: methodological aspects and palaeoclimatic implications. Earth-Science Reviews 54 (1-3), 193-211.

Snyder, S.L., Duval, J.S., 2003. Design and construction of a gamma-ray spectrometer system for determining natural radioactive concentrations in geological samples at the US Geological Survey in Reston,
Virginia. US Geological Survey Open-File Report 03-29 (on-line only) $\langle$ http://pubs.usgs.gov/of/2003/of03-029/〉.

Topper, R., Spray, K.L., Bellis, W.H., Hamilton, J.L., Barkman, P.E., 2003. Ground Water Atlas of Colorado. Colorado Geological Survey, Department of Natural Resources, Special Publication, vol. 53, 210pp. Wheeler, R.L., 2005. Known or suggested Quaternary tectonic faulting, central and eastern United States - new and updated assessments for 2005. US Geological Survey Open-File Report 2005-1336, 37pp. 〈http://pubs.usgs.gov/of/2005/1336/pdf/OFR-2005-1336.pdf $\rangle$.

Wintle, A.G., Murray, A.S., 2006. A review of quartz optically stimulated characteristics and their relevance in single-aliquot regeneration dating protocol. Radiation Measurements 41 (4), 269-291. 